\title{
The analysis of pore space parameters of shale gas formations rocks within the range of 50 to $2 \mathrm{~nm}$
}

\begin{abstract}
Modern measuring techniques enable the characterization of porous materials in the range up to tens of angstroms, including imaging techniques of such small objects. The paper focuses on the methodology of pore space characterization for shale gas rocks. It presents certain aspects of pore space studies by means of porosimetric analyses, using adsorption isotherm analysis, presenting the methods for choosing physical and analytical models allowing the determination of the pore space parameters for those samples. It refers to detailed applications of selected computational algorithms, adequate for determining parameters of the rocks' pore space developed within the range of meso- and micropores, i.e. below $50 \mathrm{~nm}$ (in accordance with the IUPAC convention).
\end{abstract}

Key words: shale rocks, pore space, nitrogen adsorption analysis, pore space imaging techniques in the mesopore scale, thickness curve.

\section{Analiza parametrów przestrzeni porowej skał formacji łupków gazonośnych w zakresie od 50 do $2 \mathrm{~nm}$}

Współcześnie dysponujemy szerokim wachlarzem technik pomiarowych umożliwiających charakteryzację materiałów porowatych w zakresach sięgających dziesiątek Angstromów, łącznie z technikami obrazującymi tak małe obiekty. Niniejsze opracowanie skupia się na metodyce charakteryzacji przestrzeni porowej próbek skał zwięzłych, w tym skał formacji łupków gazonośnych. Przedstawia ono niektóre aspekty badań przestrzeni porowej za pomocą analiz porozymetrycznych metodą analizy izotermy adsorpcji, prezentując sposób doboru modeli fizycznych i analitycznych pozwalających na określanie parametrów przestrzeni porowej tych próbek. Odnosi się do szczegółowego zastosowania wybranych algorytmów obliczeniowych, adekwatnych w oznaczaniu parametrów przestrzeni porowej skał, z rozwiniętą przestrzenią porową na poziomie mezo i mikro porów, a więc w zakresie poniżej $50 \mathrm{~nm}$ (zgodnie z konwencją IUPAC).

Słowa kluczowe: skały formacji łupków gazonośnych, przestrzeń porowa, metody izotermy adsorpcji, techniki obrazowania przestrzeni porowej w zakresie mezoporów, metoda $\mathrm{BJH}$, krzywa grubości adsorbatu $t(x)$.

\section{Introduction}

The analysis of the pore space in solids, including geological samples, can be carried out using a number of analytical methods like: various microscopic techinques - both optical and scanning electron microscopy (SEM), X-ray tomography, $\mu$-CT, XRM. Beyond them also NMR method which is using the effect of nuclear magnetic resonance, also electrical and pycnometric techiques, as well as others based on density analyses. Finally porosimetric techniques. As the most popular of them we have to mention: mercury porosimetry (MICP) and analyses of the adsorption isotherm usually using nitrogen, argon or $\mathrm{CO}_{2}$ as the adspobtive gas [15].
The above set of methods is not comprehensive. Only the most important techniques or those most widely used in geological laboratory practice have been listed here.

At the same time, a separate extensive study could be devoted to each of the aforementioned analytical methods. The existing works summarising the topic are monographs many hundreds of pages long, like the book "Experimental Methods in the physics of porous media", edited by Po-Zen Wong [24].

It is worth paying particular attention to techniques of 3D reconstruction of the pore space. This methodology has been dynamically developing, both in terms of technology and 
results elaboration, with special emphasis on the applications dedicated to geology. Year after year papers presenting these techniques become, if not outdated, at least not reflecting the full analytical and technological possibilities. Among the newest solutions for volume reconstruction, FIB-SEM (Focused Ion Beam Scanning Electron Microscopy) should be mentioned, as one of much more often commercially used in last few years. It uses a high resolution electron microscope coupled with an ion gun which allows imaging in $3 \mathrm{D}$, detals of a few nm. Another one which is also not destructive but of slightly lower resolusion is XRM (X-ray Microscopy) so-called X-ray microscop may operate down to $50 \mathrm{~nm}$. Finally, the newest but still not very popular microscopic method, enabling visualisation of a single nanometre size objects is the HIM technique (Helium Ion Microscopy) so-called helium microscopy. Its great advantage, apart from $3 \mathrm{D}$ space visualisation at extremely high resolutions, is its non-destructive nature, even for samples of very low phase transition temperature, up to now hardly measurable using traditional electron microscopy, even of the highest generation.

This paper focuses on the analytical-computational aspects used in measuring techniques most widely applied for shale gas formations. It describes various aspects of analysis using the adsorption isotherm method and mercury porosimetry, primarily due to measuring ranges adequate for studies in a wide range of pore space diameters, reaching such small diameters as meso- and micro-porous, and hence, in accordance with the IUPAC nomenclature [23], diameters within the range of $50 \div 2 \mathrm{~nm}$ and below $2 \mathrm{~nm}$. These techniques, at relatively short analysis times, provide information of substantial reliability, especially for the smallest pores ranges. The data processing methodology for the adsorption isotherm analysis, as well as the interpretation of the results may be complex, and hence it must be continuously developed depending on individual applications. The best situation would be in connection with the aforementioned similar research techniques.

The interest in such ranges, from a practical point of view, was poorly justified in the case of conventional deposits rocks.
However, knowledge of the pore space on such a small scale has recently become more and more important.

It is significant due to the necessity of considering the meso- and micro-porous range in the case of the evaluation of gas shale formations resources, and also for understanding and modelling processes related to their exploration.

The literature reports, computational procedures for unconventional deposit parameters assessment, which is widely used, inter alia in the USA, it clearly indicates the necessity to consider the pore spaces from the meso- and micro-pores ranges according to their contribution in total estimated gas volume, mainly as adsorbed gas - which is reaching even few dozen percent of overall balance according to this estimation procedure [25].

It should be noticed that despite a drastic drop of hydrocarbon fuels prices on global markets, and hence a decline of hydrocarbons production from unconventional deposits' profitability, the USA's fuel balances in recent years considered a permanent increase in the "shale gas" share in the "energy mix". As early as in 2010 the USA's gas sources from shale deposits covered more than $14 \%$ of the total US demand for natural gas. Only the production from the Marcellus reservoir between 2011 and 2014 increased more than three times, from 135.94 million $\mathrm{m}^{3} / \mathrm{d}$ to more than 413.47 million $\mathrm{m}^{3} / \mathrm{d}$.

Therefore, both from the technological and from the analytical point of view, in the USA's geological conditions many problems related to shale gas production were successfully resolved. Hence, we should presume that with time and with changes of economic conditions in the fuel markets, gas production from unconventional deposits may also become profitable in European countries.

Therefore, it is justified to develop analytical methodologies and techniques adequate for, and adapted to, the characteristics of such deposits in Europe. These techniques primarily include adsorption isotherm analysis with adequate computational techniques, supported with such methods as mercury porosimetry or scanning electron microscopy and X-ray microscopy, as well as nuclear magnetic resonance technique and others.

\section{Instruments}

A porosimeter - an adsorption isotherms analyser - TriStar II 3020 Micromeritics, with the SmartPrep samples preparation station. Thanks to the courtesy of the FEI Company, an FEI Helios NanoLab ultra-high resolution microscope, together with access to a polishing ion mill for hihghly efficient sample preparation by polishing.

\section{Methodology}

As mentioned earlier, porosimetric analyses are classified as one of the basic petrophysical analitcal methods. The mercury porosimetry is most often used to study the pore space of rocks, primarily due to the time of analysis and the high reliability of this method. But with the appearance of the need for a detailed determination of pore space parameters 
in the range below $20 \mathrm{~nm}$ this method may be insufficient. Although the range of meso-pores is covered by the MICP measurements, in the case where the analysis is to apply to organic matter porosity, the results may be affected by high pressures of mercury (60 $000 \mathrm{PSI}$ ), used at the measuring ranges up to $3 \mathrm{~nm}$, on the delicate organic phase of the sample.

Therefore, in certain cases it is necessary to apply a supplementary method which, together with obtained results of the analysis, will be the aim of this paper.

The technique of adsorption isotherm analysis gives, among other parameters, possibilities to determine pore dimensions distribution function. It also enables a precise determination of specific surface areas of porous materials and of the pore space volume [5].

In the most typical version, the measurement consists of the analysis, most frequently with the use of nitrogen, gas which is adsorbed on the surface of the studied sample, at the liquid nitrogen temperature (in a nitrogen bath). Variants of this method allow measurements with the use of other gases, e.g., carbon dioxide or methane, and others. The temperature at which the experiment is carried out must be adapted to the adsorbed gas type. The choice of the adsorbed gas (adsorbate) is most often dictated by practical reasons, e.g. to perform the most accurate measurement of the specified range - e.g. micropores usage of $\mathrm{CO}_{2}$ is most convenient. Instead, if we are concerned with the most precise measurement of the specific surface area, it is worth deciding to do the measurement using argon, and if we are interested in methane adsorption phenomena, this gas would be used. However, to compare the data with other authors' papers it is necessary to pay attention in order to make comparisons for the same adsorbate.

We must be aware that this methodology has already been developed for many years, mainly for the needs of catalyst and sorbent technology. The first, and frequently up to now the basic theories, were suggested in the second half of the nineteenth century and at the beginning of the twentieth, e.g. Kelvin's (Thomson) theory - 1871 [23], or Langmuir's theory laying foundations for the whole methodology, which was published as early as in 1916 [17].

Result processing and interpretation is not trivial, and is related to the necessity of a proper choice of physical model for the measuring interesting poresize range. Although today this could be done semi-automatically, with the application of sophisticated specialised analytical software (in our case it is - Micromeritics TriStar II 3020 v1.03 software, delivered together with the instrument), the work with this data requires the knowledge and involvement of the operator, who can make the decision related to the choice of interpretation models, and to a detailed research procedure for individual types of analysed samples.
Therefore, after obtaining the results in the form of isotherm of gas adsorption on the surface of the studied sample (our adsorbent - e.g. a porous material), among others based on the isotherm shape, a decision should be made on the interpretation model.

Such an isotherm is the relationship between the amount of adsorbed gas which is used for the analysis, this amount is given on the axis of ordinates under STP conditions, i.e. standard temperature and pressure, and relative pressures $\left(P / P_{0}\right)$ dimensionless - describing the axis of abscissa. The axis of abscissa will always maintain the maximum range up to the value of 1 , because the maximum pressure $P$ obtained above the analysed sample is the saturated vapours pressure $P_{0}$, and hence the $P / P_{0}$ maximum will always have the value of 1 . An example of adsorption isotherm, the values of witch, will also be used in further calculations in the experimental part of the paper, is shown in Figure 1.

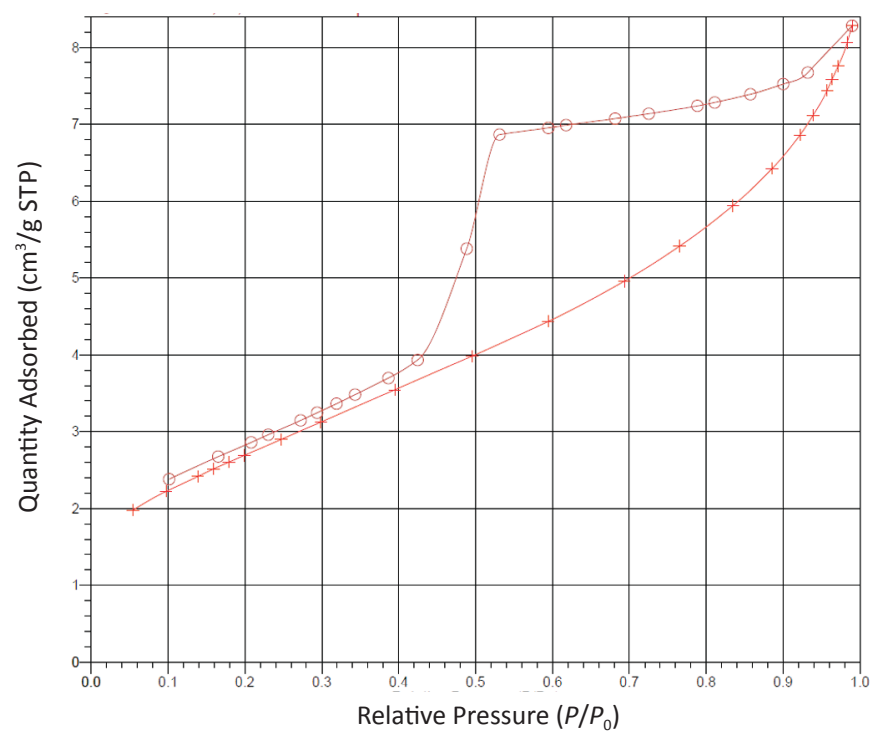

Fig. 1. Adsorption isotherm of a shale sample from polish shale gase basin. The curve marked with croses is the adsorption branch; the desorption branch is marked with circles

As a result of choice of the model, which will be used at the stage of data processing, we can determine a group of parameters characterising our sample. The diagram in Figure 2 presents the specification of best known and used theories together with parameters obtainable by their use. One of the most important selection criteria is expected, interesting, range of the analysed pore sizes. Selected models are only outlined below, while their application, in the context of studies on rocks from gas shale formations, together with a series of results, was presented in the paper by Dudek and KowalskaWłodarczyk in 2014 [10], as well as by the study [1] together with original source texts of the authors of presented theories [2-4, 6-9, 12-14, 16-22]. 


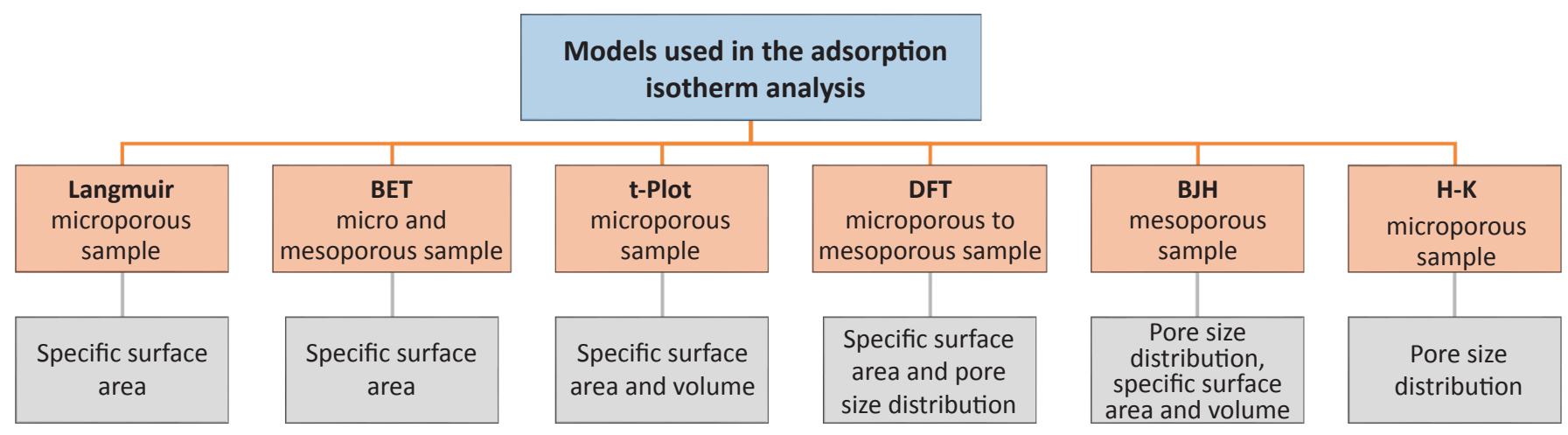

Fig. 2. Schematic simplified specification of theories/models used in the interpretation of results from the adsorption isotherm analysis method

From a practical point of view it is also necessary to consider that some of the theories mentioned below required providing, as equation parameters, additional data related to the analysed sample, as well as frequently predefining the expected pore types, e.g. broken into, silt, cylindrical or spherical. This is not always practically possible, or requires applying supplementary techniques, e.g. high resolution electron microscopy or high resolution techniques for the pore space reconstruction.

With respect to the criterion of the analysed pore sizes range, the choice of methodologies may be as follows.

For the smallest pore range, micropores, we use a series of models: in this range the determination of the specific surface will most often be possible using a one-layer Langmuir theory [16-18], the t-plot model [21], which additionally allows determining the pore space volume, giving in addition some information about the pores distribution, and also the H-K model (i.e. Horwath-Kawazoe) [13] providing information on the pore sizes' distribution and their volume.

One of the most universal and most frequently used model, mainly due to the wide range of sizes of the analysed pore spaces is BET model (Brunauer, Emmet and Teller) [4]. It is used primarily to determine specific surface areas, covering ranges of both micro and meso pores, up to macro pores. The BET theory of multilayer adsorption is a development of Langmuir's model.

The mesopores range $(2 \div 50 \mathrm{~nm})$ is particularly important in porosimetric analyses of shale gas formation rocks. First of all, this is because of the substantial share of this range in the balance of the total pore space volume of 'shale rocks', and also because of transport phenomena occurring in this pore diameter range. The micro range is also very important from this point of view.

As mentioned earlier, the range of smallest pores, is not always well estimated using other research techniques. It is related, among others, to the destructive nature of studies using other techniques. Therefore, the basic theory used in the adsorption isotherm analysis for the mesopore range will be much more accurately described.

The studies on PSD (Pore Size Distributions), on the pore space volume, and on the specific surface area can be carried out using assumtions based on the capillary condensation phenomenta which occurs inside the pore space of the analysed sample witch means applying the BJH (Barret, Joyner and Halenda) mode [2]. It is appropriate primarily for the medium size pores range, hence for mesopores, but also for part of larger pores (the macro pore range).

The BJH theory assumes that in the relative pressures $P / P_{0}$ range of $(0.4 \div 0.98)$, that is corresponding most frequently to the mesopore diameters, within the pore space the aforementioned effect of capillary condensation occurs (gas adsorbs in pores, in the form of liquid, for pressures close to the saturated vapours pressure). An increase in the pressure results in a growing thickness of the adsorbate layer up to complete pore filling. The thickness of the liquid adsorbate layer on the pore walls surface (adsorbent) is denoted as $t(x)$. A few physical models exist, describing its changes with changes of relative pressures. Hence $t$ is a function of $P / P_{0}$. The denotation $t(x)$ or directly $t\left(P / P_{0}\right)$ may be encountered. The value of $t(x)$ changes for each next relative pressure, the algorithm for the layer thickness determination predicts calculations with steps of decreasing relative pressures. So it is convenient to work with the desorption branch. The most universal $t(x)$ form is Halsey's relationship [12], which is approximately independent of the adsorbent type (that is the studied porous sample). Also, the following relationships may be mentioned among various possible equations for $t(x)$ : by Harkins and Jura [13], Broekhoff and de Boer [6] and KrukJaroniec-Sayari [16].

The BJH model is based on the Kelvin (Thomson) theory [28], linking relative pressures $\left(P / P_{0}\right)$ with pore radii (relationship 1). Assuming a cylindrical or silt geometry, it is possible to determine the total pore space and their size distribution, hence it is possible to obtain a function of volume vs. radius 
$V=f(r)$, which after differentiation will allow the obtaining of a curve of pore radii distribution against their volume.

$$
\frac{1}{r_{k, x}}+\frac{1}{r_{k, y}}=\frac{-R T}{\sigma V_{m}} \ln \frac{P}{P_{0}}
$$

where:

$r_{k, x}, r_{k, y}$ - radii of meniscus curvature in planes perpendicular to each other, $\sigma$ - surface tension of liquid adsorbate,

$V_{m}$ - molar volume of adsorbate,

$R$ - the gas constant,

$T$ - the absolute temperature,

$P_{0}$ - the saturated vapour pressure above a flat surface of liquid adsorbate,

$P$ - the vapour pressure above the meniscus, at which condensation or evaporation will occur.

\section{Studies}

Because of the particular importance of the BJH model for the determination of pore space distributions, mainly in the mesopores range, this paper follows - based on the example - the behaviour of pore space distributions using the aforementioned model and applying its various variants. That is selecting various types of adsorption layer thickness curves.
The model was chosen primarily due to the type of basic isotherm, which is characterised by a substantial share of the mesopore range (Fig. 1). With a fairly good approximation it may be described as the type IV isotherm in accordance with the IUPAC convention. Additionally, this observation is confirmed by the image from an ultra-high resolution electron microscope (Fig. 7).

\section{Detailed conditions of the experiment}

Measurements were carried out with the use of gaseous nitrogen, performing the experiment at liquid nitrogen temperature, using a three-stand Micromeritics TriStar II 3020 instrument. A sample of slightly less than 1 gram mass was crushed, then dried in a dryer during approx. $24 \mathrm{~h}$ at $105^{\circ} \mathrm{C}$, and then weighed with the accuracy of 4 significant places. Then it was dried again in a stream of a dry nitrogen, in a programmed 120 minute temperature cycle rising up to $120^{\circ} \mathrm{C}$ and then during another $60 \mathrm{~min}$ utes cooled down, (also in a scavenge of a dry nitrogen), to a temperature of $25^{\circ} \mathrm{C}$.

The sample prepared in this way was again accurately weighed and placed in the measuring system, where after a few times of preliminary rinsing of the sample with helium a partial vacuum of appropriate value was automatically created inside the measuring tube, so that after immersing a test tube with the sample in the liquid nitrogen and reaching thermodynamic equilibrium a further analytical procedure could start.

The sample characteristics (i.e. the mineral composition, the TOC content and the total porosity) were chosen in such a way that it would not differ from a typical sample for numerous Polish gas shales. Its characteristics were described by the following values: total porosity of $6.18 \%$, TOC content of $4.9 \%$, mineral composition (dominating components contents): quartz $-27 \%$, feldspars $-1.3 \%$, calcite $-9.7 \%$, clay minerals $-50 \%$, others $-12 \%$.

At the computation stage the behaviour of the computational algorithm of the BJH theory was based on a set of real data, using various equations for the adsorbate layer thickness $t(x)$. The characteristics obtained by means of the adsorption isotherm method were also confirmed using a high resolution FEI Helios scanning electron microscope; the results are presented in Figure 7.

\section{Results of experiment - computation stage}

Differences resulting from the application of various layer thickness equations are presented in a collective graph in Figure 3 and also in the next Figures 4, 5 and 6. They present pore space distributions (functions of volume incremental vs. pore diameters, cumulative curves of pore spaces, and also functions of specific surface incremental, and cumulative curves for specific surface areas). Each of the attached graphs is a family of curves calculated based on the experimental data for the same sample, using individual analytical algorithms implemented in the utility software. Each curve originated from a different equation for the adsorbate layer thickness using the algorithm at the same type of correction. Table 1 presents these equations for the nitrogen adsorbate.

Table 1 also presents values of dominating pore radii determined using each of layer thickness models as well as an averaged pore radius for each model.

In Figures 3-6: the curve for the Halsey equation is presented in blue, the equation acc. to the Harkins-Jura adsorbate 
layer theory in red, results obtained using the Broekhoff equation are marked in grey, curves obtained using the KrukJaroniec-Sayari equation are marked in dark blue. The last

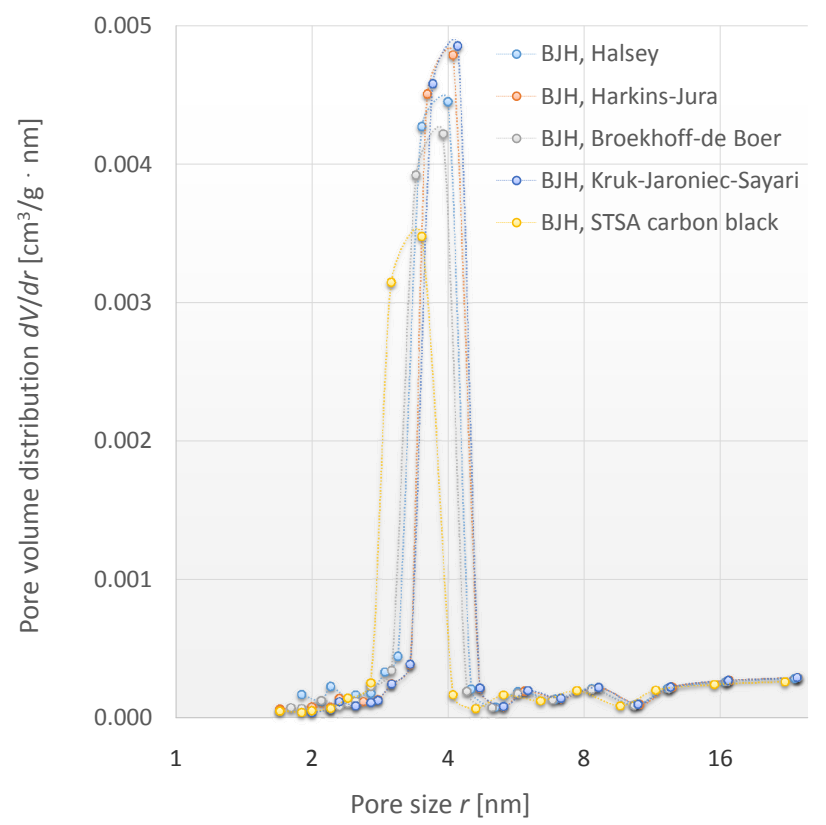

Fig. 3. The pore volume distribution curves determined from the BJH model, using various curves of adsorbate layer thickness according to Halsey, Harkins-Jura, Broekhoff, Kruk-Jaroniec-Sayari, and STSA Carbon Black models. Visible shifts of the dominating maximum position of the distribution, and also in ranges below the main maximum

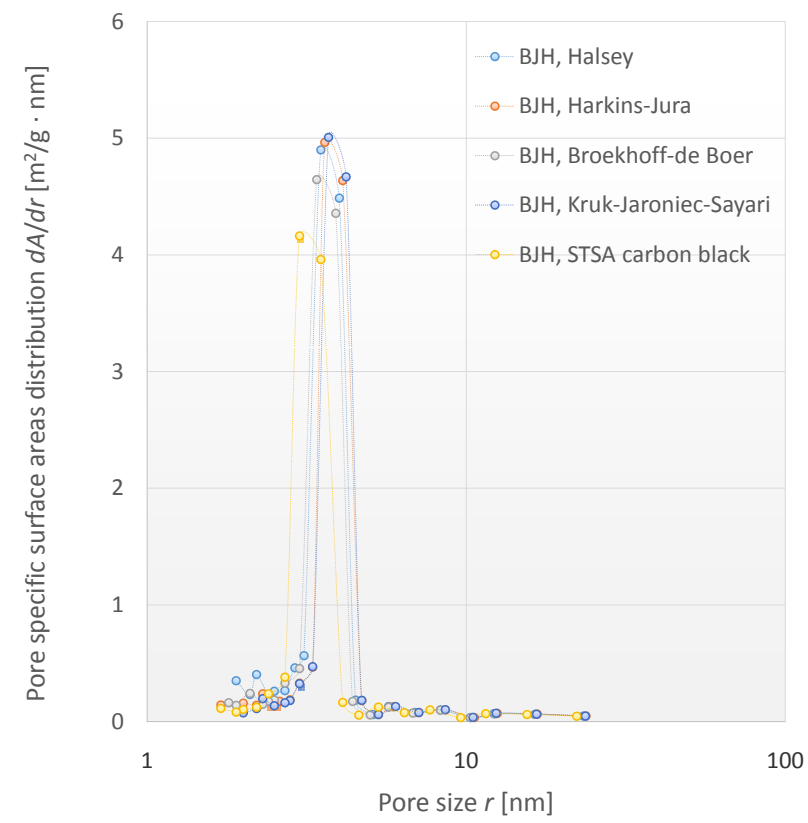

Fig. 5. Specific surface distributions curves determined from the BJH model using various curves of the adsorbate layer thickness acc. to models: Halsey, Harkins-Jura, Broekhoff, Kruk-Jaroniec-Sayari, and STSA Carbon Black. Visible shift of the dominating maximum position of the specific surface distribution curve, marked in yellow, was calculated in accordance with the STSA Carbon Black model implemented in Micromeritics Tristar II software v. 1.03.

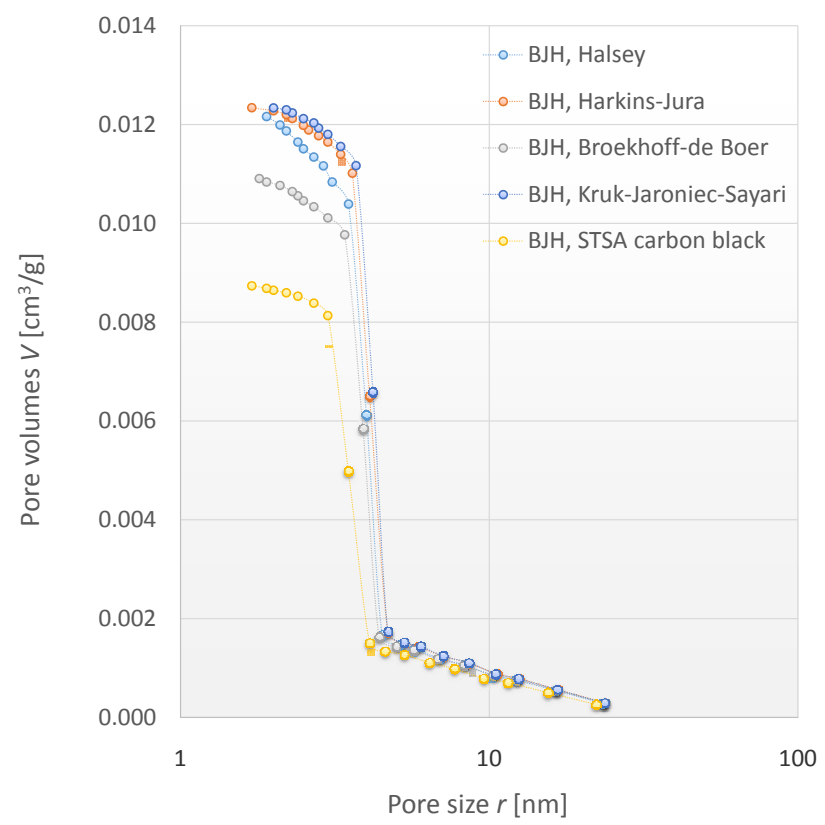

Fig. 4. Cumulative pore volume curves determined from the BJH model using various curves of the adsorbate layer thickness acc. to models: Halsey, Harkins-Jura, Broekhoff,

Kruk-Jaroniec-Sayari, and STSA Carbon Black. Visible differences in the total pore volume determined using individual thickness curves

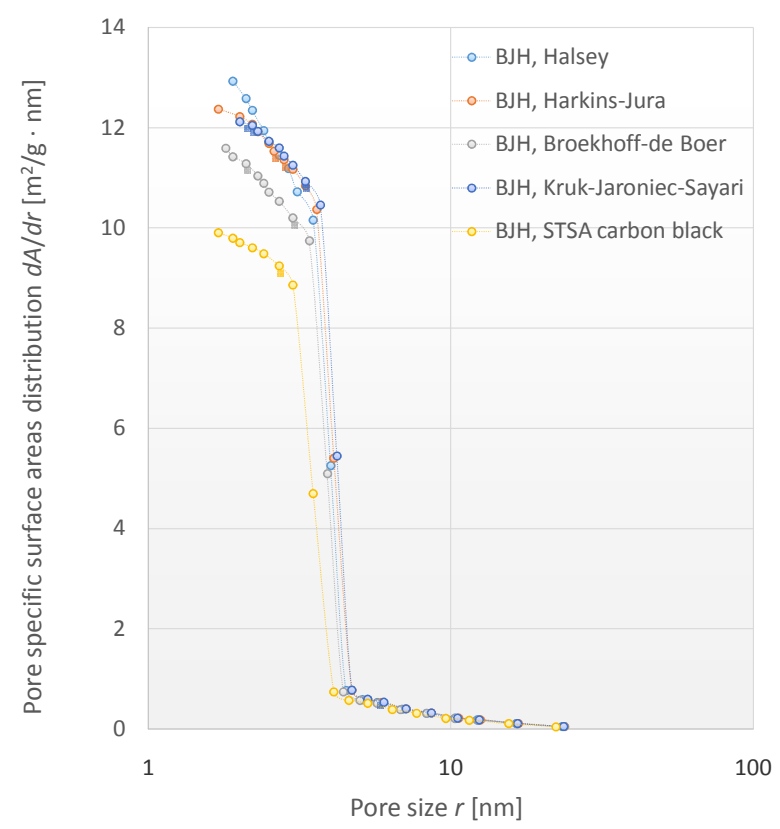

Fig. 6. Cumulative specific surface curves determined from the BJH model using various curves of the adsorbate layer thickness acc. to models: Halsey, Harkins-Jura, Broekhoff, Kruk-Jaroniec-Sayari, and STSA Carbon Black 
Table 1. Specification of equations used in calculations and dominating pores radii in accordance with the Micrometrics computation models [29]

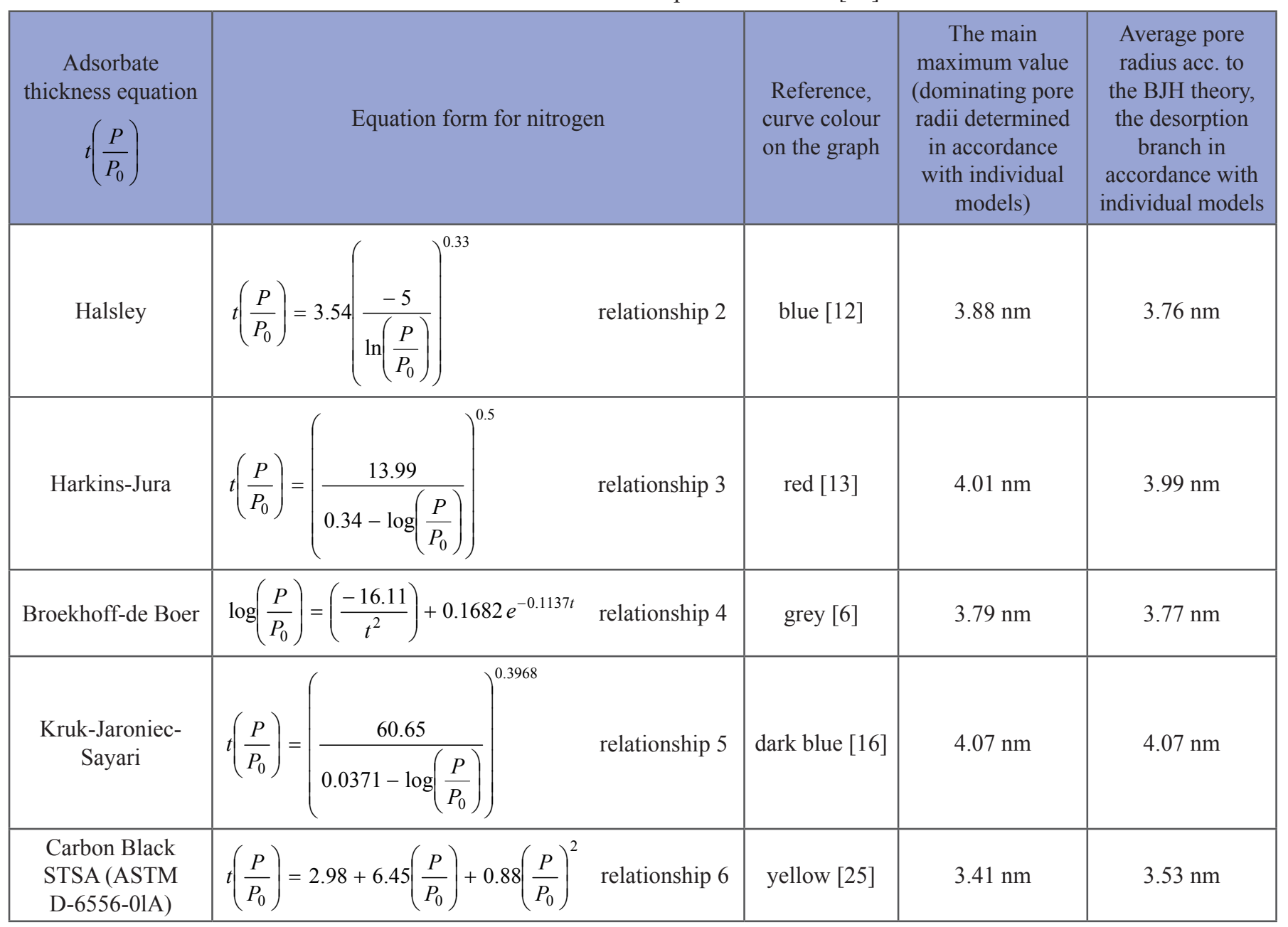

\section{Discussion of results and summary}

The analysis of values collected in Table 1 together with Figures 3-6 clearly shows that results obtained from various models differ between themselves, and although there are not drastic differences on the scale of $1.7 \div 20 \mathrm{~nm}$ measuring range, which covers the $\mathrm{BJH}$ model for the analysed data, an attempt to refer these values to detailed results related to, e.g. clay minerals and their type present in the sample, obtained from the XRD method, may be difficult. However it is possible to assess qualitatively that any of the selected models is consistent with images obtained using ultra-high resolution scanning microscopy (Fig. 7).

These differences are related to both estimated dominating pores radii and to total specific surfaces in the analysed ranges, or total pore space volumes - in principle it should be said that the differences in condition of usage various thicknes curve equations occur for all modelled parameters and distributions (i.e. distribution of pore sizes and specific surface area), which anyway is a trivial conclusion due to the interrelationships between these parameters.
However, it should be emphasised that despite the fact that the BJH theory properly considers the phenomenon of gas-liquid adsorption (gas adsorption/desorption on the layer already preliminary covering the pores) and theoretically the results should be independent of the adsorbent type, the layer thickness equation based on the carbon standard (carbon black STSA - relationship 6) implemented by authors of the Micromeritics Tristar 3020 software gives results substantially deviating from the other models. This means that caution should be exercised when selecting a model for the thickness curve, at the same time comparing results between themselves, and that closer attention should be paid to details of the applied model comparing only results obtained using the same models.

Continuing the analysis of the obtained values, it is possible to notice that the closest results are those for the pore radii distributions' maximum position obtained using thickness equations for the Harkins-Jura (relationship 3) and the KrukJaroniec-Sayari (relationship 5) models. Instead, for averaged radii the values obtained from the Halsey (relationship 2) 
and Broekhoff-de Boer (relationship 4) equations are the closest ones.

At the same time, the highest value of total specific surface areas and total volumes, for the analysed range, are predicted by the Halsey $t(x)$ relationship, and values significantly smaller in each of the distributions are shown by the relationship based on the carbon black standard.

In papers on geological applications of the BJH model the thickness curve based on the Halsey model is used quite often, so it seems that good practice, in particular for comparative purposes, will consist in using this model anywhere it is possible.

The characteristic of results discrepancy in relation to various versions of the layer thickness equation, in the BJH analyses, depends to a large extent on the characteristics of the analysed materials, which is also shown by the results of Šolcová et al. [26]. They performed a similar analysis for a model borate glasses (so-called CPR glasses) of controlled porosity and a narrow distribution of pore diameters in the meso range. In their paper, differently from us, they have shown similar results for the radii distributions' maxima for the Halsey and Harkins-Jura models.

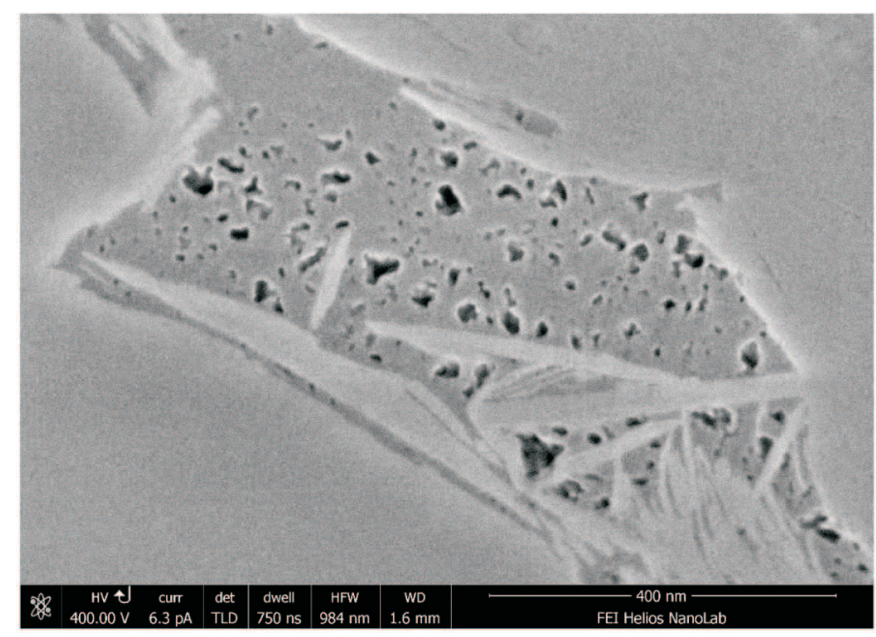

Fig. 7. High resolution SEM microscopic image of pore space of analysed sample obtained using FEI Helios NanoLab scanning electron microscope (the analysis at the accelerating voltage of $0.4 \mathrm{kV}$ - a non-destructive value for the organic matter) - the sample was previously ion polished. Pores visible inside the organic matter. The smallest of them, of substantial population, correspond to values determined in the adsorption isotherm analysis. Visible substantial population of pores $3.5 \div 5.5 \mathrm{~nm}$ in diameter

\section{Acknowledgements}

Special acknowledgements to the FEI Company for analysing rock samples of shale formations and for visualisation of the organic matter existing in them.

Please cite as: Nafta-Gaz 2015, no. 12, pp. 983-991, DOI: 10.18668/NG2015.12.06

Article contributed to the Editor 4.09.2015. Approved for publication 19.10.2015.

The article is the result of research conducted in connection with the project: The methodology for determining sweet spots on the basis of geochemical, petrophysical, geomechanical properties based on the correlation of laboratory test results with geophysical measurements and 3D generating model, co-funded by the National Centre for Research and Development as part of the programme BLUE GAS - POLISH SHALE GAS. Contract No. BG1/MWSSSG/13.

\section{Literature}

[1] Adesida A.: Pore size distribution of Barnet shale using nitrogen adsroption data. University of Oklahoma 2011.

[2] Barrett E. P., Joyner L. S., Halenda P. P.: The determination of pore volume and area distributions in porous substances. I. Computations from nitrogen isotherms. Journal of the American Chemical Society 1951, vol. 73, no. 5, pp. 373-380.

[3] Broekhoff J. C. P., de Boer J. H.: The surface area determination in intermediate pores. [in:] Int. Symp. Surf. Area Determ. 1969, pp. 97-121.

[4] Brunauer S., Emmett P. H., Teller E.: Gases in Multimolecular Layers. Journal of American Chemical Society 1938, vol. 60, no. 12 , pp. 309-319.

[5] Choma J., Jaroniec M.: Porowatosc adsorbentow i katalizatorow: klasyczne metody analizy, ich mozliwosci i ograniczenia. Ochrona Środowiska 2001, vol. 2, pp. 3-8.

[6] de Boer J. H., Linsen B. G., Osinga T. J.: Studies on pore systems in catalysts. VI. The universal t-curve. Journal of Catalysis 1965, vol. 4, pp. 643-648.

[7] de Boer J. H., Linsen B. G., van der Plas T., Zondervan G. J.: Studies on pore systems in catalysts. VII. Description of the pore dimensions of carbon blacks by the t method. Journal of Catalist 1965, vol. 4, pp. 649-653.

[8] de Boer J. H., van den Heuvel A., Linsen B.: Studies on pore systems in catalysts. IV. The two causes of reversible hysteresis. Journal of Catalysis 1964, vol. 3, pp. 268-273.

[9] de Boer J. H., Linsen B. G.: Studies on pore systems in catalysts. II. The shapes of pores in aluminum oxide systems. Journal of Catalysis 1964, vol. 3, pp. 38-43.

[10] Dudek L., Kowalska-Wlodarczyk M.: Pragmatyczne podejscie do adsorpcji $w$ skalach lupkowych zloz typu shale gas. Nafta-Gaz 2014, no. 7, pp. 416-424.

[11] Halsey G.: Physical adsorption on non-uniform surfaces. The Journal of Chemical Physics 1948, vol. 16, pp. 931-937.

[12] Harkins W. D., Jura G.: An adsorption method for the determination of the area of a solid without the assumption of a molecular area, and the area occupied by nitrogen molecules on the surfaces of solids. The Journal Chemical Physics 1943, vol. 11, pp. 431

[13] Horvath G., Kawazoe K.: Method for the calculation of effectiv pore size distribution in molecular sieve carbon. 
Journal of Chemical Engineering of Japan 1983, vol. 16, pp. $470-475$.

[14] Jaroniec M., Kruk M., Olivier J. P., Koch S.: A new method for the mesoporous, accurate pore size analysis of MCM-41 and other silica-based materials. [in:] Proc. COPS-V, Heidelberg, Germany 1999.

[15] Klobes P., Meyer K., Munro R. G.: Porosity and specific surface area measurements for solid materials. National Institute of Standards and Technology, U.S. Government Printing Office, Washington 2006.

[16] Langmuir I.: The adsorption of gases on plane surfaces of glass mica and platinum. Journal of American Chemical Society 1918, vol. 40, pp. 1361.

[17] Langmuir I.: The constitution and fundamental properties of solids and liquids. Journal of American Chemical Society 1916, vol. 38, pp. 2221.

[18] Langmuir I.: The evaporation, condensation and reflection of molecules and the mechanism of adsorption. Physical Review 1916, vol. 8, pp. 149-176.

[19] Lippens B. C, de Boer J. H.: Studies on pore systems in catalysts. III. Pore-size distribution curves in aluminum oxide systems. Journal of Catalysis 1964, vol. 3, pp. 44-49.

[20] Lippens B. C., de Boer J. H.: Studies on pore systems in catalysts. $V$. The t method. Journal of Catalysis 1965, vol. 4, pp. 319-323.

[21] Lippens B. C., Linsen B. G., De Boer J. H.: Studies on pore systems in catalysts. I. The adsorption of nitrogen; apparatus and calculation. Journal of Catalysis 1964, vol. 3, pp. 32-37.

[22] Magee R. W.: Evaluation of the external surface area of carbon black by nitrogen adsorption. Ruber Chemistry and Technology 1995, vol. 68 , no. 5 , pp. 590.
[23] McNaught A. D.: Compendium of chemical terminology. The Gold Book. International Union of Pure and Applied Chemistry, 1997.

[24] Po-Zen Wong: Methods in the physics of porous media. Experimental Methods in the Physical Sciences. Volume 35. Academic Press, Elsevier, San Diego, London, Boston, New York, Sydney, Tokyo, Toronto 1999.

[25] Shale gas and shale oil resource assessment methodology. EIA/ARI World Shale Gas and Shale Oil Resource Assessment; http://www.adv-res.com/pdf/00_EIA_ARI_Study_Methodology June_2013_FINAL.pdf (access on: June 2015).

[26] Šolcová O., Matějová L., Schneider P.: Pore-size distributions from nitrogen adsorption revisited: Models comparison with controlled-pore glasses. Applied Catalysis A, General 2006, vol. 313, no. 2, pp. 167-176.

[27] Such P.: Co to wlasciwie znaczy porowatosc skal lupkowych. Nafta-Gaz 2014, no. 7, pp. 411-415.

[28] Thomson S. W.: On the equilibrium of vapour at a curved surface of liquid. Philosophical Magazine 1871, series 4, pp. 448-452.

[29] TriStar II 3020 Operator's Manual V 1.03 Micromeritics, 2009.

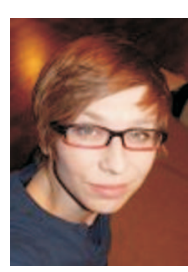
Maja MROCZKOWSKA-SZERSZEŃ Ph.D., Eng. Assistant Professor at Geology and Geochemistry Department

Oil and Gas Institute - National Research Institute ul. Lubicz 25 A

31-503 Kraków

E-mail: maja.mroczkowska@inig.pl

\section{OFFER}

\section{DEPARTMENT OF GEOLOGY AND GEOCHEMISTRY}

Scope of activity:

- petrophysical laboratory measurements:

" density, porosity, pore space parameters and gas permeability analysis,

" macro- and micro-fractures measurements in thin sections and cubics,

" petrographic investigations, diagenetic processes,

- geochemical laboratory analysis:

» Rock-Eval pyrolysis of cores and cuttings (determination of TOC); free hydrocarbons content, residual coal; hydrocarbons potential),

» elementary analysis of hydrocarbons and kerogene $(\mathrm{C}, \mathrm{H}, \mathrm{N}, \mathrm{S} ; \mathrm{H} / \mathrm{C}$ and $\mathrm{O} / \mathrm{C}$ ratio),

» chemical and physicochemical investigations of natural gases,

" "Head space" and occluded gas investigations,

» investigations of rock extracts (SARA); GC and GC/MS of saturated and aromatic fractions, biomarker analysis,

» investigations of oil (physical and chemical properties; GC analyses of crude oil; GC/ MS analyses of saturated and aromatic fractions; correlation oil/oil and oil/source rock);

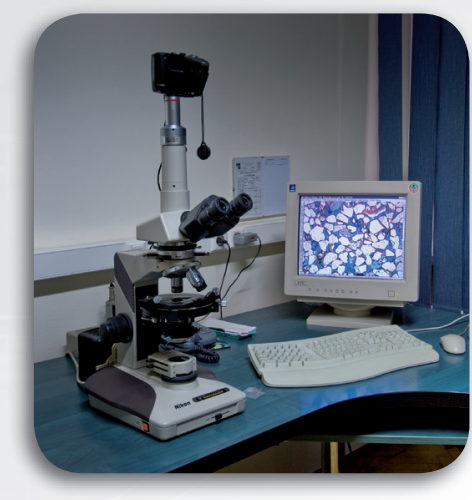

- $\quad$ reservoir and basin scale studies

- $\quad$ well log data interpretation (petrophysics, source rock evaluation, fractures);

- $\quad 3 D$ structural, facies and petrophysical properties modeling with well and seismic data;

- development of geomechanical models;

- volumetric calculations for hydrocarbon reserves and resources, uncertainty modeling;

- petroleum Sedimentology: facies- and sequence stratigraphy analysis of cores, outcrops, well log and seismic data;

- $\quad 4 D$ Petroleum systems modeling studies.

\section{CONTACT}

Grzegorz Leśniak, PhD Eng.

25 A Lubicz Str., 31-503 Cracow, POLAND

Phone: +4812617 7687 Fax: +481243038 85

E-mail: grzegorz.lesniak@inig.pl

OIL AND GAS INSTITUTE

National Research Institute 